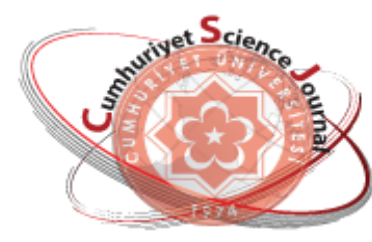

e-ISSN: 2587-246X

ISSN: $2587-2680$

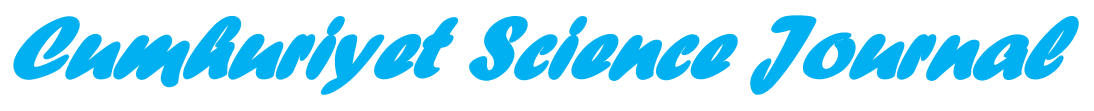

CSI

Cumhuriyet Sci. J., Vol.38-3 (2017) 450-460

\title{
The Effects of Oxytocin and Oxytocin Receptor Antagonist Atosiban on the Carbonic Anhydrase and Acetylcholinesterase Enzymes from Lung Tissues of Rats
}

\author{
Ümit M. KOCYIGIT \\ Vocational School of Health Services, Cumhuriyet University, 58140 Sivas, TURKEY \\ Received: 09.06.2017; Accepted: 28.08.2017 \\ http://dx.doi.org/10.17776/csj.340483
}

\begin{abstract}
The purpose of our studies is to assist in fully understanding the role of oxytocin in the live metabolism by examining the effects of oxytocin, oxytocin receptor antagonist atosiban, and oxytocinatosiban chemicals injected to the rats on activities of carbonic anhydrase (CA) and acetylcholinesterase (AChE) enzymes in the lung tissue of the rats. For this purpose, 4 different groups each of which contains 6 rats formed. (Control group, oxytocin administered group, atosiban administered group, and both oxytocin and atosiban administered group). The rats were necropsied after an hour from the injection of chemicals into the rats intraperitoneally. The lung tissues of the rats were extracted. Carbonic anhydrase and acetylcholinesterase enzymes activities were measured for the tissues. All the experimental results were provided as mean $\pm \mathrm{SD}$ (mean standard deviation). Because of the data was compatible with the normal range, it was tested via variance analysis (ANOVA) and then, significance was determined by the Tukey test. Statistical significance was identified to be $\mathrm{p}<0.05$.
\end{abstract}

Accordingly, it was observed that there was neither a decrease of enzyme activities in oxytocin and atosiban administered groups, nor a significant change of enzyme activities in both oxytocin and atosiban administered group. Also, we observed that oxytocin reduced carbonic anhydrase enzyme activity as a systemic effect. We think that this result may contribute to remedy of lung related diseases progressing with oxygen and carbon dioxide transport disorders.

Keywords: Carbonic Anhydrase, Oxytocin, Atosiban, enzyme activity, rat

\section{Sıçanların Akciğer Dokusunda Oksitosin ve Oksitosin Reseptör Antagonisti Atosiban'm Karbonik Anhidraz ve Asetilkolinesteraz Enzim Aktiviteleri Üzerine Etkileri}

Özet: Çalışmamızda, sıçanlara enjekte edilen oksitosin ve oksitosin reseptör antagonisti olan atosibanın- sıçan akciğer dokusunda karbonik anhidraz (CA) ve asetilkolinesteraz (AChE) enzim aktiviteleri üzerine etkilerinin incelenerek, oksitosinin canlı metabolizmadaki rolünün tam olarak anlaşılmasına yardımcı olmak amaçlanmıştır. Bu amaçla, her biri 6 adet sıçandan oluşan 4 farklı grup oluşturuldu. (Kontrol grubu, oksitosin verilen grup, atosiban verilen grup ve oksitosin ile atosibanın birlikte verildiği grup). Siçanlara kimyasallar intraperitoneal olarak enjekte edildikten bir saat sonra sıçanlar nekropsiye alındı. Sıçanların akciğer dokuları çıkarıldı. Bu dokular için CA ve AChE aktiviteleri ölçüldü. Tüm deneysel sonuçlar ortalama \pm SH (ortalamanın standart hatası) olarak ifade edildi. Veriler normal dağılıma uygunluk gösterdiği için varyans analizi (ANOVA) ile test edildi ve daha sonra anlamlılı Tukey test ile belirlendi. İstatistiksel anlamlılık $\mathrm{p}<0.05$ düzeyinde tanımlandı. Buna göre, oksitosin ve atosiban verilen gruplarda enzim aktivelerinde azalma, oksitosin ile atosibanın birlikte verildiği gruptaki enzim aktivelerinde ise anlamlı bir değişiklik olmadığ görüldü.Ayrıca Oksitosinin sistemik bir etki olarak CA enzim aktivitesini azalttığını gözlemledik. Bu sonucun akciğerle alakalı olan akciğer oksijen karbondioksit taşınmasında bozuklukla seyreden hastalıklara katkısı olabileceğini düşünmekteyiz.

Anahtar Kelimeler: Karbonik Anhidraz (CA), Oksitosin, Atosiban, enzim aktivite, rat

\footnotetext{
* Corresponding author. Email address: ukocyigit@cumhuriyet.edu.tr

http://dergipark.gov.tr/csj C2016 Faculty of Science, Cumhuriyet University
} 


\section{INTRODUCTION}

Oxytocin (OT) is a peptide-structured hormone released from the supraoptic (SOP) and paraventricular (PVN) nuclei at hypothalamus and comprises nine amino acids. OT is released from these two nuclei as well as the other nuclei near hypothalamus

(forebrainbundle, bedstriaterminalis, zona incerta, substantia innominata, etc.). OT is transferred to the pituitary stem by axonal transport. Then, it is released into the general circulation via the terminal buttons in the posterior pituitary. After getting into the systemic circulation, the OT affects the uterine muscle, the mammary gland and the seminiferous tubules in particular. In addition, OT acts as a classical neurotransmitter on smaller nerves in the caudal paraventricular nuclei of the hypothalamus [1].

Oxytocin is a good example of biological molecules, where an organism can be used for many different purposes. Along with its known effects, OT has many other effects which have been revealed recently and a part of which is still under discussion. Some of the physiological effects of OT can be described as its effects on reproduction, diabetes metabolism, thymus physiology and immune system, sexual and nutritional behaviors, cardiovascular system, medulla spinalis and sensation of pain [2].

An analogue of desamino-oxytocin, atosiban is a nonapeptide, and a vasopressin / oxytocin receptor antagonist (VOTra). Atosiban inhibits the inositol triphosphate release (performed via oxytocin) from the myometrial cell membrane. As a result, it reduces the release of intracellular calcium stored in the sarcoplasmic reticulum of myometrial cells and the flow of calcium in the extra cellular liquid through voltage-dependent calcium channels. In addition, atosiban suppresses prostaglandin $\mathrm{E}$ (PGE) and prostaglandin F (PGF) released from decidua via oxytocin [3].

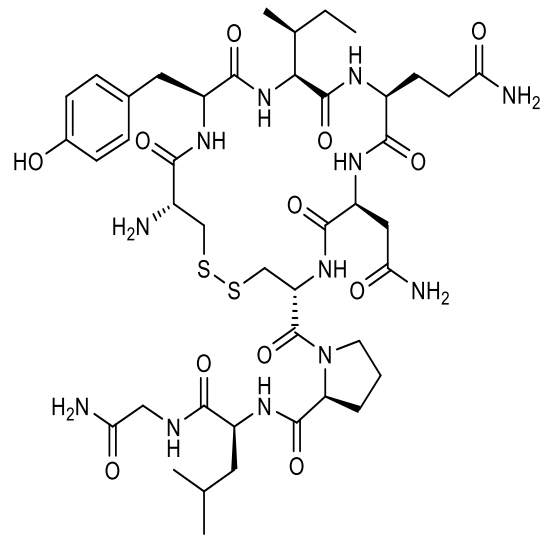

Figure 1: Chemical structure of oxytocin.

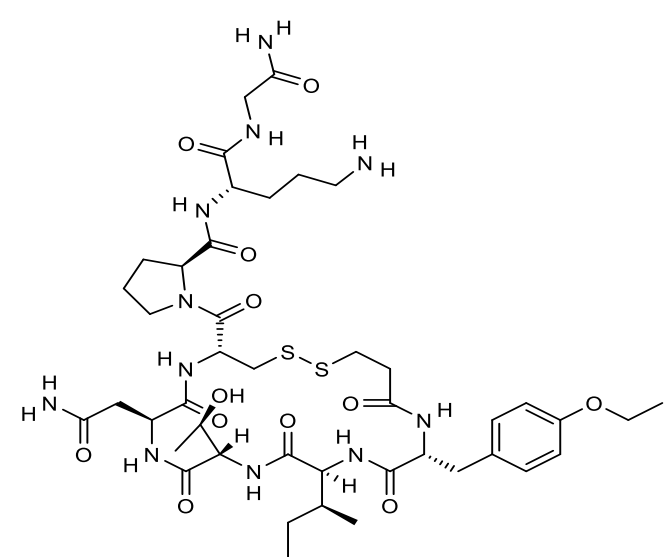

Figure 2. Chemical structure of atosiban.

Carbonic anhydrase (CA, carbonate hydrolase, E.C. 4.2.1.1) is a metalloenzyme that is very important for biological systems and contains a zinc $\left(\mathrm{Zn}^{+2}\right)$ ion in its active site [4-7]. Carbonic anhydrase is a very important enzyme, which basically ensures that the $\mathrm{CO}_{2}$ emerging from respiration is dissolved in water, transported and driven out of body as well as plays an important role in many physiological events such as acidbase balance, ion exchange, regulation of the cardiovascular system $[8,9]$. The enzyme that is initially isolated from human erythrocytes has been studied via many living organisms and tissues [4].

Acetylcholinesterase (AChE, acetylcholine acetylhydrolase, EC: 3.1.1.7) is a fundamental enzyme for neurotransmission, and reduces the agglomeration of active neurotransmitters during synaptic division in extreme cells, and hydrolyzes the neurotransmitter acetylcholine [10-12]. It has been noted that cholinergic therapeutics for Alzheimer's disease (AD) contains 
acetylcholinesterase inhibitors (AChEI), acetylcholine precursors ( $\mathrm{ACh}), \mathrm{ACh}$ expression facilitators, post-synaptic muscarinic M1 receptor agonists [13,14].

When previous studies are examined, it has been observed that there are many works intended to investigate agents and factors affecting the activities of carbonic anhydrase and acetylcholinesterase enzymes at various types of creatures and various tissues. In these studies, the interactions between $\mathrm{AChE}$ and cyclic thioureas [15], hetaryl sulfonamides [16], Mannich bases [17], urea derived from phenethylamines [18], tetrahydropyrimidines [19], diaryl ethers [20], $\beta$ lactams [21], benzene sulfonamides [22, 23], and tetrahydropyrimidine-5-carboxylates [24] as well as the interactions between CA isoenzymes and caffeic acid phenethyl ester [25], polyphenols and phenolic acids [26, 27], benzotropones [28], bromophenols [29, 30], dopaminergic compounds [31, 32], sulfamides [33, 34, 35], sulfonamides [36], acyl sulfonamides [37], benzene sulfonamides [38], 1, 3, 5-trisubstitutedpyrazolines [39], tetra lone-based 1.4benzothiazepine derivatives [40], novel eugenol derivatives [41], some natural sulfonamide derivatives [42] and novel (3aR, 4S, 7R, 7aS)-2(4-((E)-3-(3-aryl)acryloyl)phenyl)-3a, 4, 7, 7atetrahydro-1H 4.7 methanoisoindole-1.3(2H)dione derivatives [43], benzylsulfamides [44] have been investigated. In our study, the purpose is to investigate the effects of oxytocin, oxytocin receptor antagonist atosiban, and oxytocinatosiban chemicals injected to the rats on the activities of CA and AChE enzymes in the lung tissues of rats, which has not been studied before. This is because identifying the role of oxytocin precisely is complicated due to the pulsatility of oxytocin secretion in live metabolism and difficulty of measuring the level of hormone. However, it is expected that a contribution is made for fully understanding the role of oxytocin in the light of the data obtained.

\section{METHOD}

\subsection{Animals and Lab:}

Animal experimentations were carried out under the granted approval from the Local Ethics Committee for Animal Experimentation of Cumhuriyet University with the issue number of 65202830-050.04.04-99. Adult 24 male standard Wistar albino rats that were weighing between 240 to 260 gr housed in cages and kept stress-free were used in the study. All rats were supplied from the Animal Experimentation Unit of Cumhuriyet University, and they were contained in an isolated room having 12:12 hour illumination cycle with room integers of $22 \pm 2^{\circ} \mathrm{C}$ temperature and $53 \pm 5 \%$ relative humidity. Ad libitum feeding regime using standard rat ration along with fresh water were provided. All manipulations were conducted on rats between 9 am to $3 \mathrm{pm}$ inside a continuously monitored room. All rats were divided into four distinct groups by randomly choosing six rats into each group. Resulting groups were as follows: Group 1 as control; Group 2 for oxytocin (40 IU / kg (160 $\mu \mathrm{g}$ $/ \mathrm{kg})$; Group 3 for atosiban $(2.5 \mathrm{mg} / \mathrm{kg})$; and Group 4 for oxytocin (40 IU / kg (160 $\mu \mathrm{g} / \mathrm{kg})$ ) and atosiban $(2.5 \mathrm{mg} / \mathrm{kg})$ [45-47].

\subsection{Chemicals:}

p-nitrophenyl acetate (PNF) and protein assay reagent were provided from Sigma-Aldrich Co. (GmbH, Germany). All chemicals for analytical grade were purchased from Merck (Germany).

\subsection{Tissue Extraction and Homogenate Preparation:}

Following the IP injections of chemical compounds, rats were taken into necropsy after 60 min. Lungs were removed, and tissue extraction was carried out. Blood and other contaminants were eliminated by washing three times with $0.9 \%$ $\mathrm{NaCl}$. Homogenate preparation was requiring initial dispersion of tissues in Ultra-turrax apparatus. By doing so, tissues were broken up into much smaller fragments. Soon after this step, resulting fragments were broken up by using liquid nitrogen, and homogenized in a buffer 
solution containing $3 \mathrm{~mL} / \mathrm{gr} 25 \mathrm{mM}$ Tris $\mathrm{HCl} / 0.1$ $\mathrm{M} \mathrm{Na}_{2} \mathrm{SO}_{4}(\mathrm{pH}=8.7)$.

\subsection{Carbonic Anhydrase Activity Assessment:}

\subsubsection{Hydratase Activity:}

Hydratase activeness needs to be assessed for the calculation of CA activity [49], and the proposed method was modified by Rickli et al. [50]. later on [50]. The modified method lays in Foundation of assessing the $\mathrm{pH}$ level increments as caused by the $\mathrm{H}^{+}$discharge by the $\mathrm{CO}_{2}$ hydration which is then measured by the bromine thymol blue indicator in a time plot.

To conduct the assessment, following reagents were added and mixed in a blind tube: $1 \mathrm{~mL}$ vernal buffer $(0.025 \mathrm{M}, \mathrm{pH}: 8.2) ; 0.1 \mathrm{~mL} 0.04 \%$ bromine thymol blue; $0.6 \mathrm{~mL}$ purified water; and $2.5 \mathrm{~mL} \mathrm{CO}$ solution. Thus, total reaction volume was $4.2 \mathrm{~mL}$. A chronometer was used to calculate elapsed time of color change from bromine thymol blue to yellowish green $(\mathrm{pH}$ 6.3) starting from the instance of the addition of $\mathrm{CO}_{2}$ solution as indicated as $t_{0}$. From the total reaction volume, $0.05 \mathrm{~mL}$ water dismissed and the same amount of enzyme was added to the sample tube. Then the same color change assessment was conducted.

An enzyme unit (EU) conforming to enzyme activity method has a definition of the amount of enzyme which decreases the color change time of $\mathrm{CO}_{2}$ solution compared to the absence of enzyme. For each volume of enzyme solution, following formula was used to calculate the enzyme unit value $[47,51]$ :

$\mathrm{EU}=\frac{\mathrm{t}_{\mathrm{o}}-\mathrm{t}_{\mathrm{c}}}{\mathrm{t}_{\mathrm{c}}}$

The same approach was used in the determination of activities from hemolysates, pure enzyme solutions, and in inhibition studies.

\subsubsection{Esterase Activity:}

Kinetic and inhibitory studies mostly require the assessment of the esterase activity. Foundation of this assessment lays in the presence of esterase activity of CA. Hydrolyzation of CA substrate $p$ nitrophenyl acetate (PNA) was allowed to provide either $p$-nitrophenol or $p$-nitrophenolate which in turn gave absorbance at $348 \mathrm{~nm}$ [52,53]. Mechanism of action detailed below:

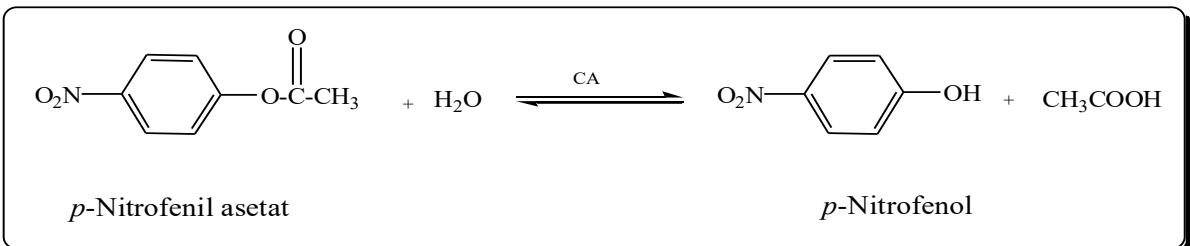

Figure 3. $p$-Nitrophenylacetate (PNA) - p-nitrophenol conversion mechanism.

At $348 \mathrm{~nm}$ wavelength, both $p$-nitrophenol or $p$ nitrophenolate give absorbance values, and decomposition of $\mathrm{H}^{+}$from phenol groups does not alter the outcome [52, 53]. As p-nitrophenyl acetate has very little to none absorbance values at this wavelength, it can be used as blind.
Table 1 shows the procedure observed for activity assessment when $1 \mathrm{~mL}$ quartz vessel was used for each sequence of substrates that were forming the treatments.

Table 1. The solutions used at each $1 \mathrm{~mL}$ quartz vessel for esterase activity.

\begin{tabular}{|c|c|c|}
\hline Materials Used & Control Tube $(\mu \mathrm{L})$ & Sample Tube $(\mu \mathrm{L})$ \\
\hline Tris-SO $\mathrm{SO}_{4}(0.05 \mathrm{M} ; \mathrm{pH}: 7,4)$ & 467 & 467 \\
\hline$P$-Nitro phenol acetate & 333 & 333 \\
\hline Pure Water & 200 & 167 \\
\hline Enzyme Solution & - & 33 \\
\hline Total Volume & 1000 & 1000 \\
\hline
\end{tabular}


Once the reaction mixture as shown in Table 1 prepared, absorbance values were checked for every $15 \mathrm{sec}$, and the absorbance difference at 348 $\mathrm{nm}$ wavelength at $25^{\circ} \mathrm{C}$ was calculated at the end of the 3rd minute. Before replacing water with the enzyme solution, the spectrophotometer was reset to zero, and the same assessment carried over.

Daily preparation of substrate solution containing PNA was done with following procedure: $27.2 \mathrm{~g}$ of PNA was added into $1 \mathrm{~mL}$ acetone and allowed to dissolve entirely which then transferred into 49 $\mathrm{mL}$ distilled water and thoroughly mixed. Because of the constrained solubility of ester, maximum of $3 \mathrm{mM}$ substrate solution was possible to be prepared. Acetone was preferably chosen due to its negligible inhibitory effects on hydrolysis among other organic solvents [53]. Esterase activeness assessments were also used in kinetic measurements.

\subsubsection{Acetylcholinesterase Activity Measurement Method}

The outlying basis of the method includes catalysis reaction of cholinesterase where acetylcholine dissolved into both thiocholine and acetate. As a product, when thiocholine was reacted with 5,5'-dithiobis (2-nitrobenzoic acid) (DTNB) reaction results in yellow colored 5-thio2-nitrobenzoic acid. Color change results were measured at $412 \mathrm{~nm}$ wavelength [47, 54] (Table 2).

Table 2. Vessel content in the study performed via acetylcholinesterase method.

\begin{tabular}{lll}
\hline Materials Used & Control Tube $(\boldsymbol{\mu L})$ & Sample Tube $(\boldsymbol{\mu L})$ \\
\hline Tris-HCl & 100 & 100 \\
Pure Water & 790 & 780 \\
Sample & - & 10 \\
DTNB & 50 & 50 \\
Enzyme Solution & 10 & 10 \\
Acetylcholinethioiodide & 50 & 50 \\
\hline
\end{tabular}

\subsection{Statistical Assessment}

All results were presented as mean and standard deviation values, and as the obtained data were suitable to fit in a normal range, variance analysis (ANOVA) was conducted, and Tukey test was performed to determine significance which was deemed at $\mathrm{p}<0.05$ point [47].

\section{RESULTS AND DISCUSSION}

The results that show the effect of the chemicals on the activity of carbonic anhydrase and acetylcholinesterase enzymes in the lung tissue are indicated in Table 3. 
Table 3. The results that show the effect the chemicals on the activity of carbonic anhydrase and acetylcholinesterase enzymes in the lung tissue.

\begin{tabular}{|c|c|c|c|c|c|c|c|c|}
\hline & iable & $\begin{array}{c}\text { Control } \\
\mathbf{X} \pm \text { SD }\end{array}$ & $\begin{array}{c}\text { Oxytocin } \\
\mathbf{X} \pm \mathrm{SD}\end{array}$ & $\begin{array}{c}\text { Atosiban } \\
\mathbf{X} \pm \text { SD }\end{array}$ & $\begin{array}{c}\text { Oxytocin } \\
+ \text { Atosiban } \\
\mathbf{X} \pm \text { SD }\end{array}$ & ANOVA & $\begin{array}{c}\text { Comparison } \\
\text { Group }\end{array}$ & $\begin{array}{l}\text { Post hoc } \\
\text { p-value }\end{array}$ \\
\hline \multirow[t]{2}{*}{$\begin{array}{c}\text { CA } \\
\text { Activity } \\
\text { (EU/mL) }\end{array}$} & Esterase & $4.14 \pm 0.16$ & $2.97 \pm 0.24$ & $2.96 \pm 0.23$ & $4.20 \pm 0,21$ & $\begin{array}{c}\mathrm{F}=55,026 \\
\mathrm{P}=0,001\end{array}$ & $\begin{array}{l}1 \mathrm{Vs} 2 \\
1 \mathrm{Vs} 3 \\
1 \mathrm{Vs} 4 \\
2 \mathrm{Vs} 3 \\
2 \mathrm{Vs} 4\end{array}$ & $\begin{array}{l}0.001 \\
0.001 \\
0.955 \\
0.999 \\
0.001\end{array}$ \\
\hline & Hydratase & $215.89 \pm 13.37$ & $138.63 \pm 11.27$ & $134.61 \pm 6.85$ & $227.26 \pm 8.29$ & $\begin{array}{c}\mathrm{F}=115,336 \\
\mathrm{P}=0,001\end{array}$ & $\begin{array}{l}1 \mathrm{Vs} 2 \\
1 \mathrm{Vs} 3 \\
1 \mathrm{Vs} 4 \\
2 \mathrm{Vs} 3 \\
2 \mathrm{Vs} 4 \\
\end{array}$ & $\begin{array}{l}0.001 \\
0.001 \\
0.331 \\
0.924 \\
0.001 \\
\end{array}$ \\
\hline $\begin{array}{c}\text { AChE } \\
\text { Activity } \\
\text { (EU/mL) }\end{array}$ & & $0.18 \pm 0.014$ & $0.13 \pm 0.012$ & $0.16 \pm 0.013$ & $0.19 \pm 0.009$ & $\begin{array}{c}F=115.336 \\
P=0.001\end{array}$ & $\begin{array}{l}1 \text { Vs } 2 \\
1 \text { Vs } 3 \\
1 \text { Vs } 4 \\
2 \text { Vs } 3 \\
2 \text { Vs } 4\end{array}$ & $\begin{array}{l}0.001 \\
0.168 \\
0.468 \\
0.001 \\
0.001\end{array}$ \\
\hline
\end{tabular}

Upon assessment of the activities of carbonic anhydrase enzyme per esterase method (Graph 1), it was observed that there is; a statistically significant difference between control group and the oxytocin administered group $(\mathrm{p}<0.05)$, a statistically significant difference between control group and the atosiban administered group $(\mathrm{p}<0.05)$, a statistically significant difference between the oxytocin administered group and both oxytocin and atosiban administered group $(\mathrm{p}<0.05)$, and a statistically significant difference between atosiban administered group and both oxytocin and atosiban administered group $(\mathrm{p}<0.05)$.

Upon assessment of the activities of carbonic anhydrase enzyme per hydratase method(Graph 1), it was observed that there is; a statistically significant difference between control group and the oxytocin administered group $(\mathrm{p}<0.05)$, a statistically significant difference between control group and the atosiban administered group $(p<0.05)$, a statistically significant difference between the oxytocin administered group and both oxytocin and atosiban administered group $(\mathrm{p}<0.05)$, and a statistically significant difference between atosiban administered group and both oxytocin and atosiban administered group $(p<0.05)$. Since the results obtained here are same as the results obtained from the esterase method, it's understood that there is an integrity.

Upon assessment of the activities of acetylcholine esterase enzyme, it was observed that there is; a statistically significant difference between control group and the oxytocin administered group $(p<0.05)$, a statistically significant difference between the oxytocin administered group and both the oxytocin and atosiban administered group $(\mathrm{p}<0.05)$, and a statistically significant difference between the atosiban administered group and the oxytocin administered group $(\mathrm{p}<0.05)$. 

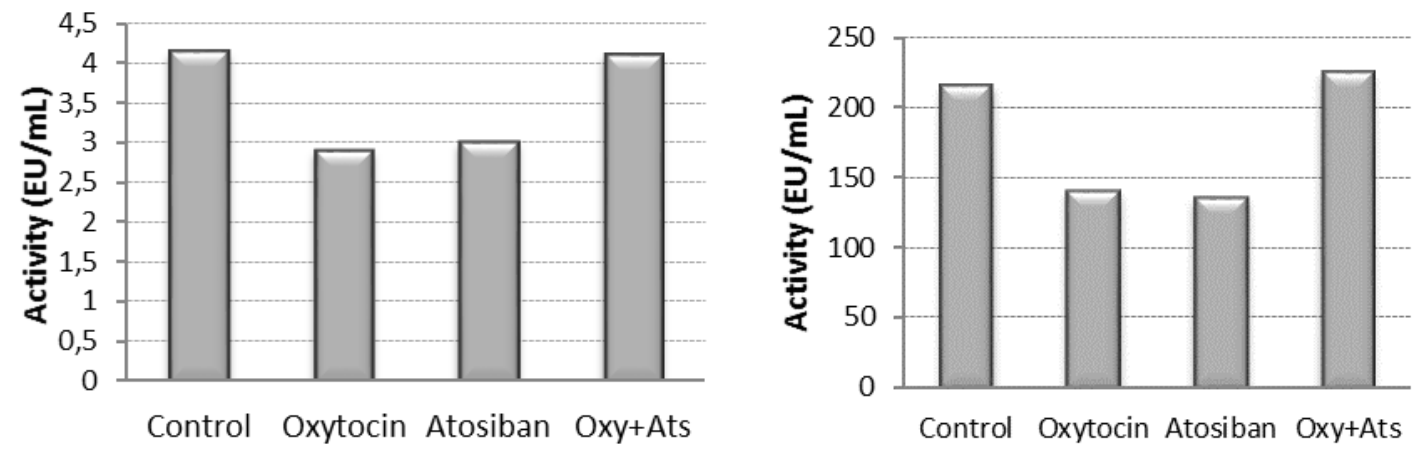

Graph 1. The effect of the chemicals in the lung tissue of a rat on the carbonic anhydrase enzyme (a: Esterase method, b: Hydratase method)

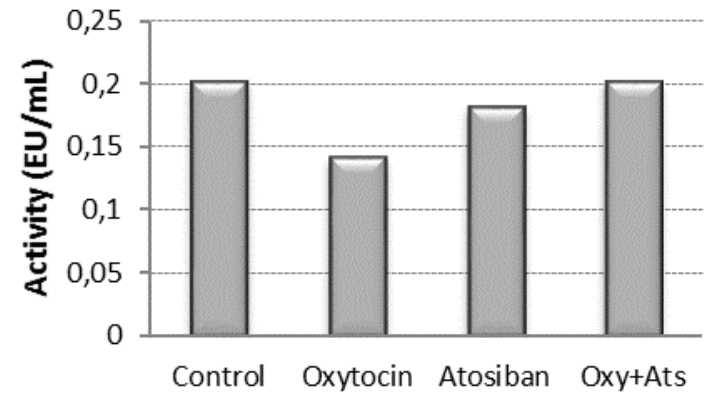

Graph 2. The effect of the chemicals in the lung tissue of a rat on the acetylcholinesterase enzyme

CA enzyme has hydratase and esterase activities. However, hydratase activity is important in physiological terms. Because, hydratase activity is important due to regulation of acid-base balance of the live organism. In the study, the activity of CA enzyme was measured via both methods and consistent results were obtained.

The most important function of carbonic anhydrase isoenzymes is to take part in respiratory action by catalyzing the reactions of conversion of $\mathrm{CO}_{2}$, which is the metabolic product of tissue capillaries, into $\mathrm{HCO}_{3}$, and conversion of $\mathrm{HCO}_{3}$ into $\mathrm{CO}_{2}$ in pulmonary capillaries. We observed that oxytocin reduced the activity of carbonic anhydrase enzyme as a systemic effect. We think that this result may contribute to remedy of lung related diseases progressing with oxygen and carbon dioxide transport disorders.
Considering the chemical structures of the oxytocin hormone and oxytocin antagonist atosiban (Figures 1 and 2), it might be considered that there is a reduction in activities of carbonic anhydrase and acetylcholinesterase due to $-\mathrm{OH}$ and $-\mathrm{NH}_{2}$ groups in their structures [47].

Absence of a significant change in the activities of enzymes in the group where oxytocin and atosiban were administered together might be considered as a result of having antagonistic effects (Graph 2).

\section{CONCLUSION}

Oxytocin is a neuropeptide hormone and yet its systemic effects have not been understood fully. In the literature, there is not any study investigating the effect of oxytocin on carbonic anhydrase enzyme. In this study, the primary reason for us to focus on the lung tissue is that lung is where blood is cleansed. And what plays the key role here is the carbonic anhydrase enzyme. In our study, we observed that oxytocin reduced the activity of carbonic anhydrase enzyme as a systemic effect (Table 3 ). We think that this result may contribute to the remedy of lung related diseases progressing with oxygen and carbon dioxide transport disorders. It has been understood that acetylcholine esterase activity is reduced by oxytocin and atosiban. 


\section{REFERENCES}

[1] Arletti, R., Benelli, A., \& Bertolini, A. (1989). Influence of oxytocin on feeding behavior in the rat. Peptides, 10(1), 89-93.

[2] Sanu, O., \& Lamont, R. F. (2010). Critical appraisal and clinical utility of atosiban in the management of preterm labor. Therapeutics and Clinical Risk Management, 6, 191.

[3] Berg, J.M.,Tymoczko, J.L., Stryer, L. (2014). Biyokimya. Palme Yayıncılık.241-247p,

[4] Gocer, H., Topal, F., Topal, M., Küçük, M., Teke, D., Gülçin, İ., ... \& Supuran, C. T. (2016). Acetylcholinesterase and carbonic anhydrase isoenzymes I and II inhibition profiles of taxifolin. Journal of Enzyme Inhibition and Medicinal Chemistry, 31(3), 441-447.

[5] Kocyigit, U. M., Aslan, O. N., Gulcin, I., Temel, Y., \& Ceylan, M. (2016). Synthesis and carbonic anhydrase inhibition of novel 2(4-(aryl)thiazole-2-yl)-3a,4,7,7a-tetrahydro1h-4,7-methanoisoindole-1,3(2h)-dione derivatives. Archiv der Pharmazie, 349(12), 955-963.

[6] Gul, H. I., Mete, E., Taslimi, P., Gulcin, I., \& Supuran, C. T. (2017). Synthesis, carbonic anhydrase I and II inhibition studies of the 1, 3, 5-trisubstituted-pyrazolines. Journal of Enzyme Inhibition And Medicinal Chemistry, 32(1), 189-192.

[7] Kucukoglu, K., Oral, F., Aydin, T., Yamali, C., Algul, O., Sakagami, H., ... \& Gul, H. I. (2016). Synthesis, cytotoxicity and carbonic anhydrase inhibitory activities of new pyrazolines. Journal of Enzyme Inhibition and Medicinal Chemistry, 31(S4), 20-24.

[8] Bhatt, A., Mahon, B. P., Cruzeiro, V. W. D., Cornelio, B., Laronze Cochard, M., Ceruso, M., \& Roitberg, A. (2017). Structure-activity relationships of benzenesulfonamide based inhibitors towards carbonic anhydrase isoform specificity. Chembiochem, 18(2), 213-222.

[9] Akıncioğlu, A., Topal, M., Gulcin, I., \& Göksu, S. (2014). Novel sulphamides and sulphonamides incorporating the tetralin scaffold as carbonic anhydrase and acetylcholine esterase inhibitors. Archiv der Pharmazie, 347(1), 68-76.

[10] Göçer, H., Akincioğlu, A., Göksu, S., Gülçin, İ., \& Supuran, C. T. (2015). Carbonic anhydrase and acetylcholine esterase inhibitory effects of carbamates and sulfamoylcarbamates. Journal of Enzyme Inhibition and Medicinal Chemistry, 30(2), 316-320.

[11] Polat Köse, L., Gülçin, İ., Gören, A.C., Namiesnik, J., Martinez-Ayala, A. L., \& Gorinstein, S. (2015). LC-MS/MS analysis, antioxidant and anticholinergic properties of galanga (Alpinia officinarum Hance) rhizomes. Industrial Crops and Products, 74, 712-721.

[12] Özbey, F., Taslimi, P., Gülçin, İ., Maraş, A., Göksu, S., \& Supuran, C. T. (2016). Synthesis of diaryl ethers with acetylcholinesterase, butyrylcholinesterase and carbonic anhydrase inhibitory actions. Journal of Enzyme Inhibition and Medicinal Chemistry, 31(S2), 79-85.

[13] Taslimi, P., Gulcin, I., Ozgeris, B., Goksu, S., Tumer, F., Alwasel, S. H., \& Supuran, C. T. (2016). The human carbonic anhydrase isoenzymes I and II (hCA I and II) inhibition effects of trimethoxyindane derivatives. Journal of Enzyme Inhibition and Medicinal Chemistry, 31(1), 152-157.

[14] Taslimi, P., Osmanova, S., Gulçin, İ., Sardarova, S., Farzaliyev, V., Sujayev, A., ... \& Kufrevioglu, O. I. (2017). Discovery of potent carbonic anhydrase, acetylcholinesterase, and butyrylcholinesterase enzymes inhibitors: The new amides and thiazolidine-4-ones synthesized on an acetophenone base. Journal of Biochemical and Molecular Toxicology, DOI: $10.1002 / j b t .21931$.

[15] Taslimi, P., Sujayev, A., Mamedova, S., Kalın, P., Gulçin, İ., Sadeghian, N., ... \& Mamedov, S. (2017). Synthesis and bioactivity of several new hetaryl sulfonamides. Journal of Enzyme Inhibition and Medicinal Chemistry, 32(1), 137-145.

[16] Gül, H. I., Demirtas, A., Ucar, G., Taslimi, P., Gulcin, I. (2017). Synthesis of Mannich 
bases by two different methods and evaluation of their acetylcholine esterase and carbonic anhydrase inhibitory activities. Letters in Drug Design and Discovery, 14(5), 573-580.

[17] Aksu, K., Özgeriş, B., Taslimi, P., Naderi, A., Gülçin, İ., \& Göksu, S. (2016). Antioxidant activity, acetylcholinesterase, and carbonic anhydrase inhibitory properties of novel ureas derived from phenethylamines. Archiv der Pharmazie, 349(12), 944-954.

[18] Garibov, E., Taslimi, P., Sujayev, A., Bingol, Z., Çetinkaya, S., Gulçin, İ., ... \& Supuran, C. T. (2016). Synthesis of 4, 5-disubstituted-2thioxo-1, 2, 3, 4-tetrahydropyrimidines and investigation of their acetylcholinesterase, butyrylcholinesterase, carbonic anhydrase I/II inhibitory and antioxidant activities. Journal of Enzyme Inhibition and Medicinal Chemistry, 31(sup3), 1-9.

[19] Özbey, F., Taslimi, P., Gülçin, İ., Maraş, A., Göksu, S., \& Supuran, C. T. (2016). Synthesis of diaryl ethers with acetylcholinesterase, butyrylcholinesterase and carbonic anhydrase inhibitory actions. Journal of Enzyme Inhibition and Medicinal Chemistry, 31(S2), 79-85.

[20] Turan, B., Şendil, K., Şengül, E., Gültekin, M. S., Taslimi, P., Gulçin, İ., \& Supuran, C. T. (2016). The synthesis of some $\beta$-lactams and investigation of their metal-chelating activity, carbonic anhydrase and acetylcholinesterase inhibition profiles. Journal of Enzyme Inhibition and Medicinal Chemistry, 31(S1), 79-88.

[21] Gul, H. I., Tugrak, M., Sakagami, H., Taslimi, P., Gulcin, I., \& Supuran, C. T. (2016). Synthesis and bioactivity studies on new 4-(3-(4-Substitutedphenyl)-3a, 4dihydro-3 H-indeno [1,2-c] pyrazol-2-yl) benzenesulfonamides Journal of Enzyme Inhibition and Medicinal Chemistry, 31(6), 1619-1624.

[22] Gul, H. I., Kucukoglu, K., Yamali, C., Bilginer, S., Yuca, H., Ozturk, I., ... \& Supuran, C. T. (2016). Synthesis of 4-(2substituted hydrazinyl) benzenesulfonamides and their carbonic anhydrase inhibitory effects. Journal of Enzyme Inhibition and Medicinal Chemistry, 31(4), 568-573.

[23] Sujayev, A., Garibov, E., Taslimi, P., Gulçin, İ., Gojayeva, S., Farzaliyev, V., ... \& Supuran, C. T. (2016). Synthesis of some tetrahydropyrimidine-5-carboxylates, determination of their metal chelating effects and inhibition profiles against acetylcholinesterase, butyrylcholinesterase and carbonic anhydrase. Journal of Enzyme Inhibition and Medicinal Chemistry, 31(6), 1531-1539.

[24] Gülçin, İ., Scozzafava, A., Supuran, C. T., Koksal, Z., Turkan, F., Çetinkaya, S., ... \& Alwasel, S. H. (2016). Rosmarinic acid inhibits some metabolic enzymes including glutathione S-transferase, lactoperoxidase, acetylcholinesterase, butyrylcholinesterase and carbonic anhydrase isoenzymes Journal of Enzyme Inhibition and Medicinal Chemistry, 31(6), 1698-1702.

[25] Innocenti, A., Sarıkaya, S. B. Ö., Gülçin, I., \& Supuran, C. T. (2010). Carbonic anhydrase inhibitors. Inhibition of mammalian isoforms I-XIV with a series of natural product polyphenols and phenolic acids. Bioorganic \& Medicinal Chemistry, 18(6), 2159-2164.

[26] Innocenti, A., Gülçin, I., Scozzafava, A., \& Supuran, C.T. (2010). Carbonic anhydrase inhibitors. Antioxidant polyphenols effectively inhibit mammalian isoforms IXV. Bioorganic \& Medicinal Chemistry Letters, 20(17), 5050-5053.

[27] Güney, M., Coşkun, A., Topal, F., Daştan, A., Gülçin, İ., \& Supuran, C. T. (2014). Oxidation of cyanobenzocycloheptatrienes: synthesis, photooxygenation reaction and carbonic anhydrase isoenzymes inhibition properties of some new benzotropone derivatives. Bioorganic \& Medicinal Chemistry, 22(13), 3537-3543.

[28] Scozzafava, A., Kalın, P., Supuran, C. T., Gülçin, İ., \& Alwasel, S. H. (2015). The impact of hydroquinone on acetylcholine esterase and certain human carbonic anhydrase isoenzymes (hCA I, II, IX, and 
XII). Journal of Enzyme Inhibition and Medicinal Chemistry, 30(6), 941-946.

[29] Gülçin, İ., Beydemir, Ş., \& Büyükokuroğlu, M. E. (2004). In vitro and in vivo effects of dantrolene on carbonic anhydrase enzyme activities. Biological and Pharmaceutical Bulletin, 27(5), 613-616.

[30] Artunç, T., Çetinkaya, Y., Göçer, H., Gülçin, İ., Menzek, A., Şahin, E., Supuran, C. T. (2015). Synthesis of 4-[2-(3,4dimethoxybenzyl)cyclopentyl]-1,2-

dimethoxybenzene derivatives and evaluations of their carbonic anhydrase isoenzymes inhibitory effects. Chemical Biology \& Drug Design, 87(4):594-607.

[31] Aksu, K., Özgeriş, B., Taslimi, P., Naderi, A., Gülçin, İ., \& Göksu, S. (2016). Antioxidant activity, acetylcholinesterase, and carbonic anhydrase inhibitory properties of novel ureas derived from phenethylamines. Archiv der Pharmazie, 349(12), 944-954.

[32] Gul, H. I., Tugrak, M., Sakagami, H., Taslimi, P., Gulcin, I., \& Supuran, C. T. (2016). Synthesis and bioactivity studies on new 4-(3-(4-Substitutedphenyl)-3a, 4dihydro-3 H-indeno [1, 2-c] pyrazol-2-yl) benzenesulfonamides. Journal of Enzyme Inhibition and Medicinal Chemistry, 31(6), 1619-1624.

[33] Göçer, H., Akıncıoğlu, A., Öztaşkın, N., Göksu, S., \& Gülçin, İ. (2013). Synthesis, antioxidant, and antiacetylcholinesterase activities of sulfonamide derivatives of dopamine-related compounds. Archiv der Pharmazie, 346(11), 783-792.

[34] Akbaba, Y., Bastem, E., Topal, F., Gülçin, İ., Maraş, A., \& Göksu, S. (2014). synthesis and carbonic anhydrase inhibitory effects of novel sulfamides derived from 1aminoindanes and anilines. Archiv der Pharmazie, 347(12), 950-957.

[35] Camadan, Y., Özdemir, H., \& Gulcin, İ. (2016). Purification and characterization of dihydropyrimidine dehydrogenase enzyme from sheep liver and determination of the effects of some anaesthetic and antidepressant drugs on the enzyme activity.
Journal of Enzyme Inhibition and Medicinal Chemistry, 31(6), 1335-1341.

[36] Sujayev, A., Garibov, E., Taslimi, P., Gulçin, İ., Gojayeva, S., Farzaliyev, V., ... \& Supuran, C. T. (2016). Synthesis of some tetrahydropyrimidine-5-carboxylates, determination of their metal chelating effects and inhibition profiles against acetylcholinesterase, butyrylcholinesterase and carbonic anhydrase. Journal of Enzyme Inhibition and Medicinal Chemistry, 31(6), 1531-1539.

[37] H. I. Gül, K. Kucukoglu, C. Yamali, S. Bilginer, H. Yuca, I. Ozturk, P.Taslimi, I. Gülçin, C. T. Supuran, (2016). Synthesis of 4-(2-

substitutedhydrazinyl)benzenesulfonamides and their carbonic anhydrase inhibitory effects. Journal of Enzyme Inhibition and Medicinal Chemistry, 31,568-573.

[38] Gul, H. I., Mete, E., Taslimi, P., Gulcin, I., \& Supuran, C. T. (2017). Synthesis, carbonic anhydrase I and II inhibition studies of the 1,3,5-trisubstituted-pyrazolines. Journal of Enzyme Inhibition and Medicinal Chemistry, 32(1), 189-192.

[39] Ceylan, M., Kocyigit, U. M., Usta, N.C., Gürbüzlü, B., Temel, Y., Alwasel, S.H., \& Gülçin, İ. (2016). Synthesis, carbonic anhydrase I and II isoenzymes inhibition properties, and antibacterial activities of novel tetralone-based 1,4-benzothiazepine derivatives. Journal of Biochemical and Molecular Toxicology, 31, e21872.

[40] Topal, F., Gulcin, I., Dastan, A., \& Guney, M., (2017). Novel eugenol derivatives: Potent acetylcholinesterase and carbonic anhydrase inhibitors. International Journal of Biological Macromolecules, 94, 845-851.

[41] Kocyigit, U. M., Budak, Y., Gürdere, M. B., Tekin, Ş., Köprülü, T. K., Ertürk, F., ... \& Ceylan, M., (2016). Synthesis, characterization, anticancer, antimicrobial and carbonic anhydrase inhibition profiles of novel (3aR, 4S, 7R, 7aS)-2-(4-((E)-3-(3-aryl) acryloyl) phenyl)-3a, 4, 7, 7a-tetrahydro-1H4, 7-methanoisoindole-1, 3 (2H)-dione 
derivatives. Bioorganic Chemistry, 70, 118125.

[42] Göksu, S., Naderi, A., Akbaba, Y., Kalın, P., Akıncıoğlu, A., Gülçin, İ., ... \& Salmas, R. E. (2014). Carbonic anhydrase inhibitory properties of novel benzylsulfamides using molecular modeling and experimental studies. Bioorganic Chemistry, 56, 75-82.

[43] Erbas O, Y1lmaz M, Anil H, Bora S, Evren V, Peker G., (2013). Oxytocin inhibits pentylentetrazol-induced seizures in the rat. Peptides, 40:141-144.

[44] Simsek Y, Celik O, Karaer A, et al., (2012) Elevated cardiac oxidative stress in newborn rats from mothers treated with atosiban, 655661.

[45] Wistrand, P.J., (2002). Carbonic anhydrase III in liver and muscle of male rats purification and properties. Upsala Journal of Medicinal Sciences, 107, 77-88.

[46] Kocyigit UM, Taskıran A, Taslimi P,Yokus A, Gulcın I, (2017). Inhibitory effects of oxytocin and oxytocin receptor antagonist atosiban on the activities of carbonic anhydrase and acetylcholinesterase enzymes in the liver and kidney tissues of rats. Journal of Biochemical and Molecular Toxicology, DOI: 10.1002/jbt.21972.

[47] Pullan, L.M. and Noltmann, E.A., (1985). Purification and properties of pig muscle carbonic anhydrase III. Biochimica et Biophysica Acta, 839, 147-54.
[48] Wilbur, K.M. and Anderson, N.G., (1948). Electrometric and colorimetric determination of carbonic anhydrase. Journal of Biological Chemistry, 176, 147-154.

[49] Rickl1, E.E., Ghazanfar, S.A.S., Gibbons, B.H. and Edsall, J.T., (1964). Carbonic anhydrase from human erythrocytes. Journal of Biological Chemistry, 239, 1065

[50] Maren, T. H., (1960). A simplified micro method for the determination of carbonic anhydrase and its inhibitors. Journal of Pharmacology and Experimental Therapeutics, 130, 26.

[51] Armstrong, J. M., Myers, D.V., Verpoorte, J.A. and Edsall, J.T., (1966). Purification and properties of human erythrocyte carbonic anhydrase. Journal of Biological Chemistry 214, 5137.

[52] Verpoorte, J. A., Mehta S, Edsall J.T. (1967). Esterase Activities of Human Carbonic Anhydrases B and C Journal of Biological Chemistry 242, 4221-4229.

Ellman, G. L., Courtney, K. D., Andres, V., \& Featherstone, R. M. (1961). A new and rapid colorimetric determination of acetylcholinesterase activity. Biochemical pharmacology, 7(2), 88IN191-9095. 